\title{
The Urgency of the Public Prosecutor's Intelligence Wiretapping Authority on Disclosure of Corruption Crimes in the Perspective of Human Rights
}

\author{
Rivaldo Valini \\ Doctoral Study Program in Law \\ Lampung University \\ Lampung, Indonesia \\ aldojks@gmail.com
}

\begin{abstract}
This study aims to examine the formulation of the authority of the Public Prosecutor's Intelligence wiretapping for the disclosure of corruption in the perspective of human rights. Basically, in terms of wiretapping on the disclosure of criminal acts of corruption, the only authority given by the government is the KPK, but the facts on the ground in disclosing the Corruption Crimes of the Attorney General's Office work after the crime took place. The prosecutor's intelligence as a tool to strengthen and support the success of law enforcement operations has a very important role. This means that the intelligence of the Prosecutor's Office is part of the sustainability of the security, order, and welfare of the Indonesian state. Based on this, it is important to reformulate the authority of the Prosecutor's Intelligence on wiretapping which began with the alleged corruption crime committed by certain individuals. In the formulation of authority, it is necessary to take into account the privacy rights of the person who committed the corruption crime which cannot be separated from the violation of one's human rights. If viewed from the perspective of human rights, wiretapping can be categorized as a form of violation of human rights, especially personal rights (privacy). What is meant by human rights violations here, according to Article 1 point 6 of Law no. 39 of 1999 concerning Human Rights is an act of a person or group of people including state apparatus, whether intentional or unintentional or negligence which unlawfully reduces, hinders, limits, and or revokes the human rights of a person or group of people. Wiretapping is a form of violation of human rights, especially the right to privacy, but restrictions on privacy rights can be limited by law, of course by fulfilling certain conditions that make the wiretapping action possible. Without the fulfillment of these conditions, the act of wiretapping is a form of arbitrariness. especially the right to privacy, but the right to privacy can be limited by law, of course by fulfilling certain conditions that make the wiretapping
\end{abstract}

action possible. Without the fulfillment of these conditions, the act of wiretapping is a form of arbitrariness. especially the right to privacy, but the right to privacy can be limited by law, of course by fulfilling certain conditions that make the wiretapping action possible. Without the fulfillment of these conditions, the act of wiretapping is a form of arbitrariness.

Keywords-Wiretapping, Corruption, Intelligence, HAM

\section{INTRODUCTION}

The legal system according to LM Friedman is composed of legal subsystems in the form of legal substance, legal structure, and legal culture [1]. These three elements of the legal system determine whether a legal system can work well or not. The legal substance usually concerns aspects of legal regulation and legal structure, more to the apparatus and legal facilities and infrastructure itself, while legal culture concerns the behavior of the community.

Law No. 17 of 2011 concerning State Intelligence was ratified on November 11, 2011, by the President of the Republic of Indonesia. In this Law, there is a debate that on the one hand wants a strong state position to realize national security and national stability through state intelligence. Meanwhile, on the other hand, he wants the role of state intelligence in realizing national security and national stability to be reduced, because it is considered to have limited the freedom and basic rights of citizens. Besides that, it also wants supervision and control of state intelligence activities, as well as openness to information that is considered intelligence information [2]. The brief description above leads to a more in-depth question of what is meant by the nature of intelligence. 
The Law on State Intelligence must be able to provide a legal umbrella for intelligence operations throughout the territory of the Republic of Indonesia so that the operations carried out have a clear legal basis or have clear and measurable authority. In addition, through the Law on State Intelligence, in the future, it can form modern intelligence organizations and activities following the principles of a democratic rule of law and has left the post-colonial or authoritarian state tradition, were in this tradition intelligence functions as a safeguard of power., not serve the public interest.

The rule of law, the function of the Prosecutor's Office is very important in realizing the law in concreto. According to Bagir Manan, realizing law in concreto is not only a phenomenon of courts or judges but also includes administrative officials who provide legal services and law enforcement [3]. The Prosecutor's Office and the Police are public institutions of law enforcement, which in the criminal justice system are the initial source of a judicial process. The main task of the Prosecutor's Office of the Republic of Indonesia is to carry out state powers in the field of prosecution and other tasks based on statutory regulations and to participate in carrying out some government and development tasks in the legal field [4].

The significance of the Prosecutor's Intelligence is to be fully aware of the position, main tasks, functions, and obligations. The Adhyaksa Corps intelligence apparatus must also be able to make a positive contribution, especially in efforts to maintain and oversee democratic practices in the country. The prosecutor's intelligence as a tool to strengthen and support the success of law enforcement operations has a very important role. This means that the intelligence of the Prosecutor's Office is part of the sustainability of the security, order, and welfare of the Indonesian state. In general, intelligence services have three basic functions: collection, analysis and, an inherent feature of the entire intelligence process is counterintelligence.

In his role as a law enforcer, the Prosecutor is one of the important elements of the components to realize justice. Prosecutors as an element of the government in enforcing regulations should be the pioneers in law enforcement. In the general explanation of Law Number 16 of 2004, it is also stated that the Prosecutor's Office is one of the law enforcement agencies to play a greater role in eradicating corruption, collusion, and nepotism (KKN). The Deputy Attorney General for Intelligence is the assistant leadership element in carrying out some of the duties and authorities as well as the functions of the Attorney General in the Judicial Intelligence sector who are directly responsible to the Attorney General [6]. The Deputy Attorney General for Intelligence is led by the Deputy Attorney General for Intelligence.
The Deputy Attorney General for Intelligence has the duty and authority to carry out the duties and authorities of the Prosecutor's Office in the field of Prosecutor Intelligence.

The existence of the Prosecutor's Office, especially its intelligence role in supporting the optimization of the performance of the Prosecutor's Office in the criminal justice system, has an important role in supporting law enforcement and justice policies, both preventive and repressive, implementing and or participating in maintaining public order and peace as well as securing national development and its results. Intelligence activities and or Intelligence operations following the needs which include the functions of investigation (LID), Security (PAM), and Raising (GAL). Intelligence activities are defined as efforts, work, and actions that are manifested in the form of investigations, security, fundraising which are carried out routinely, continuously, and based on a fixed working procedure.

With the authority possessed by the Prosecutor's Intelligence, the new formulation that will appear is the wiretapping authority of the Prosecutor's Intelligence in terms of disclosing criminal acts of corruption. So far, the wiretapping authority is only owned by the Corruption Eradication Commission $(\mathrm{KPK})$, this is the first step in renewing the authority of the Prosecutor's Intelligence. The KPK in carrying out arrest operations based on wiretapping first, this step is easier on evidence in the implementation of OTT in corruption.

The problem is studied in this research is the wiretapping authority that will be formulated by the Prosecutor's Intelligence, of course, it will be closely related to a person's human rights. Therefore, in formulating this authority, it must be specifically regulated in a new policy or regulation relating to the limits and benchmarks of the Prosecutor's Intelligence in carrying out the wiretapping authority. So that the conflict of wiretapping authority on a person's human rights can be elaborated on the special authority possessed by the Prosecution Intelligence. Because basically according to the expert on constitutional law, Ironman Putra Sidin, the issue of wiretapping creates an uncomfortable atmosphere in the lives of citizens. This issue shows the loss of guarantees against the fear of doing or not doing, the threat of privacy rights of citizens, and the human rights of citizens are threatened. The issue of wiretapping has touched the human rights aspect of a person.

\section{LITERATURE REVIEW}

\section{A. The Role of Prosecutors' Intelligence as Law Enforcers}

Intelligence comes from English, namely intelligence, intelligence. In the Indonesian English Dictionary, intelligent means intelligent, clever, while intelligence means intelligence, intelligence, 
intelligence members. Literally or in a narrow sense intelligence comes from the word intelligence or human reasoning, namely how humans with intelligence or reasoning power try to live in an increasingly complex society [7]. Each individual can solve the problems faced,

The ontological dimension of intelligence (the existence of intelligence itself) is emphasized as the brain and the senses of the human body. Hendropriyono emphasized that the principles and characteristics of intelligence institutions and operations in the world including Indonesia as the ontological nature of this intelligence are Velox (from Latin, meaning speed) and Exactus (accuracy). This means that intelligence must be able to quickly detect any potential threats, challenges, obstacles, and disturbances (ATHG), and be able to act accurately to prevent, minimize or even destroy existing threats.

Through the Bureaucratic Reform program which began in 2008, the Attorney General's Office has reformed all aspects of its organization. The main target of Bureaucratic Reform is a change in behavior to increase the capacity of the Public Prosecution Service in providing services to the community. This Prosecutor's Profile serves as a guide and direction for the Attorney General's Office in managing change by strategically placing each stage and renewal activity as part of achieving the main objectives.

Intelligence as an organization is a formal structure in a country as a forum for several human resources who have special skills and skills with special characteristics that are generally closed, aimed at securing the national interest. Intelligence as an organization or agency is used to mobilize intelligence activities following their functions, either in the form of investigation, security, or raising to achieve intelligence objectives to meet the interests of the competent and responsible superiors. Intelligence as knowledge is raw information or information material (backet) that has been assessed and processed which is then linked from some of the information obtained and processed based on the needs of the users of the information [8].

The investigation, security, and reconnaissance are the main functions of national intelligence agencies. All intelligence activities are aimed at preventing criminal activity and supporting law enforcement proactively and oppressively in the areas of ideology, politics, economy, finance, sociocultural, defense and security. State intelligence carries out the functions of investigation, security, and deployment following Article 6 of Law Number 17 of 2011

The investigation is a series of efforts, work, activities, and actions carried out with a mature plan and direction. To be able to search, find, collect, and then process information into intelligence, an investigation is necessary. Information obtained from the results of the investigation is presented as input for policy formulation and decision making. This investigation is carried out to obtain the information needed about the problem to be able to estimate the problem at hand. Investigations can be carried out with open sources at home and abroad, in open ways. To obtain information that is impossible to obtain through the open method, a closed method is used. The investigation is carried out continuously which is open and closed.

In general, an investigation is the first step or an initial effort to identify whether or not a criminal event has occurred. This investigation is carried out to conduct research based on laws and regulations to ensure that a crime has occurred or not according to a predetermined method. Intelligence carries out an investigation function and seeks on its initiative to find events that are suspected of being criminal acts to carry out their duties or usually investigators only start carrying out their duties after a report/complaint from the aggrieved party.

Security is all efforts aimed at preventing the success of the efforts and actions of other parties to obtain information about our situation, preventing the leakage and loss of information material, and interfering with the espionage activities of other parties. In its implementation, security is carried out in a directed manner to prevent or ward off enemies who harm national interests and security.

\section{B. Wiretapping in the context of human rights}

The Big Indonesian Dictionary (KBBI) explains the term wiretapping has the meaning of listening to (recording) other people's information (secrets, conversations) intentionally without that person's knowledge. Article 40 of Law Number 36 of 1999 explains that wiretapping is an act of installing additional tools or equipment on a telecommunications network or equipment to obtain information illegally. In essence, information owned by a person is a protected personal right so that wiretapping activities should be prohibited.

Wiretapping as an activity or a series of activities in the investigation and investigation is described in Article 1 number 19 of Law no. 35 of 2009. Article 31 paragraph (1) of Law no. 19 of 2016 concerning amendments to Law Number 11 of 2008 concerning ITE also explains what is meant by wiretapping. Wiretapping referred to in the article is an activity of listening (recording), deflecting (changing), and inhibiting the transmission of electronic information and electronic documents of a personal nature using wired or wireless communication networks.

Human Rights are a set of rights inherent like human existence as creatures of God Almighty, which must be respected, maintained, and protected by all for the sake of upholding the law, government, and honor and protection. As stated in Article 1 number (1) of 
Law Number 39 of 1999. In this case, human rights are not given by the community or based on positive law but are solely based on their dignity as human beings created by God. Broadly speaking, human rights can be divided as follows [10]:

- Personal rights of personality rights include freedom of expression, freedom of religion, and freedom of movement.

- Financial or property rights, that is, the right to own, buy, sell, or use something

- Human rights to equality in law and government, or what is commonly referred to as the right to legal equality.

- Political or political rights, that is, the right to participate in government, the right to vote (voting and being elected in general elections), the right to form political parties.

- Social and cultural rights such as the right to choose education and the right to develop culture.

- Rules regarding human and intellectual property or procedural rights to treatment in legal proceedings, such as arrest, search, legal proceedings, etc

When viewed from the perspective of human rights, wiretapping can be categorized as a form of violation of human rights, especially personal rights (privacy) or personal rights [11]. According to Article 1, Item 6 of Human Rights Act No. 39 of 1999, human rights violations are understood here to mean intentional, unintentional, or negligent acts by a person or a group of people. You may not interfere with or limit the human rights of an individual or group of individuals assured and/or revoked by this Act and obtain or fear a fair and correct legal solution under the applicable legal mechanism.

\section{RESEARCH METHODS}

The research method used in this paper is normative legal research. A normative or library law study is a law study conducted by examining library materials or secondary data. Studies generally distinguish between data obtained directly from the community called primary data (basic data) and data from library materials (usually called secondary data) [12].

The approach used in this study is, among other things, a quantitative approach with secondary data, including primary legal material (essential legal material, such as research results, papers, etc.) and tertiary legal material (material). is. Provides instructions or explanations for primary and secondary legal materials such as dictionaries and encyclopedias). This investigation uses primary, secondary, and tertiary legal material.

\section{RESULTS}

\section{A. Legal Urgency of the Attorney's Intelligence} Wiretapping Authority in the Prosecutor's Law

Etymologically, intelligence comes from intelligence. That is, to have a high level of intelligence or to show sharp thinking, intelligence, and intelligence. Intelligence is the ability to react or adapt quickly and appropriately to new experiences physically and mentally and to use existing knowledge experiences in the face of new facts or conditions (intelligence). Intelligence is the person responsible for finding information (observations) from someone.

Intelligence as an activity is the implementation of intelligence functions in the form of investigation, security, and raising which includes the definition of activities that are continuous and activities that are intelligence operations. Intelligence operations are intelligence activities that are carried out selectively against certain targets based on orders from the competent leadership and within a predetermined time limit[14].

Therefore, intelligence is a business activity that is performed in a way that is organized using a specific method, gaining knowledge of the problems that will be faced later and presenting it to leadership as a source of decisions, actions, or formulations. Will be done. Intelligence refers to the early perceptual process, or process commonly known as the early warning system. Secret service activities are an integral part of the early warning system and enable political decision-makers to have prior knowledge (early warning). [15].

The general role of intelligence services is to collect, analyze, and provide policymakers with the information they need to make the best decisions to reach their goals. Within the public prosecutor's office, the mission, authority, and function of the intelligence agency are carried out by:

- Deputy Attorney General for Intelligence;

- Intelligence Assistant to the High Prosecutor's Office and reports to the High Prosecutor;

- The Head of the Intelligence Section at the State Prosecutor's Office is responsible to the Head of the State Attorney's Office.

The criminal charge investigation conducted by the public prosecutor's office cannot be separated from the duties of the public prosecutor's office. That is, the public prosecutor's office must also be fully involved in the development process, among other things, to create the conditions to support and secure the public prosecutor's office. Implementation of development to build a fair and prosperous society based on Pankashira. You are obliged to participate in 
the maintenance and protection of government and state authority, as well as the protection of the interests of the community.

Besides its function to overcome various problems that exist in society, law enforcement itself contains various problems in it, so that finally the law enforcement process cannot be seen in black and white, namely merely enforcing legal norms in real events. The community hopes that law enforcement can solve various problems that exist in the community, create justice and legal certainty according to community expectations so that it will bring benefits to many people.

The tiers of control over the handling of cases are carried out starting from the Cabjari, Kejari, Attorney General's Office to the AGO, which are manifested, among others, in the form of:

- Preparation of case handling reports (results of investigations, results of investigations, results of trials);

- Exposure (results of investigations, results of investigations, plans for indictments);

- Preparation of an indictment plan before being transferred to the court;

- Submission of a plan of prosecution (rentut) before the reading of criminal charges.

The disparity in the control model for handling cases, besides consuming time and money, makes prosecutors not independent but also creates opportunities for irregularities to hide behind the work of the bureaucracy itself. The apparatus that should have carried out the eradication of corruption, but is corrupt, has almost infected all the institutions of state life [16]. On the one hand, the conventionality of the prosecutor's bureaucracy makes irregularities in the prosecutor's bureaucracy difficult to stop, because every deviation hides behind the working mechanism of case handling control. On the other hand, the conventionality of the prosecutor's bureaucracy makes the prosecutor's office lose the opportunity to realize the institutionalization of the public interest in every law enforcement policy carried out by the prosecutor's office.

Based on the explanation above, it is necessary to reconstruct the law regarding the Prosecutor's Office in terms of adding authority and a specific explanation regarding the Intelligence of the Prosecutor's Office as law enforcers. This is done so that the Prosecutor's Intelligence has a special and clear legal umbrella as law enforcers. The Prosecutor's Intelligence carries out its duties and functions as well as its authority based on Law
Number 17 of 2011 concerning State Intelligence, it does not specifically regulate in field implementation.

In Article 15 of Presidential Regulation Number 38 of 2010, the Organization and Work Procedure of the Prosecutor's Office of the Republic of Indonesia states that the scope of the Intelligence sector includes investigation, security, and raising activities. Intelligence functions to prevent criminal acts to support law enforcement, both preventive and repressive in the fields of ideology, economy, finance, socio-culture, defense, and security. Apart from that, it also prevents certain people and/or participates in maintaining public order and peace. Furthermore, in Article 16 of the Presidential Regulation, the Deputy Attorney General for Intelligence carries out the following functions:

- Policy formulation in the field of intelligence;

- Coordination and synchronization of policy implementation in the field of intelligence;

- Implementation of working relations with agencies/institutions, both at home and abroad;

- Provide technical intelligence support to other fields within the Prosecutor's Office;

- Monitoring, analysis, evaluation, and reporting of the implementation of activities in the intelligence sector;

- Carrying out other duties assigned by the Attorney General.

One of the duties and authorities of the State Intelligence Agency is to find information on allegations of a criminal act that can threaten the stability of state security. Today's intelligence touches almost all fields and sectors of people's lives.

Intelligence uses various means to find these answers. The method used by intelligence is by carrying out a series of activities to collect, search, explore and record all the facts that exist according to the circumstances that occurred, data from sources who can be trusted to be true, informational materials (baked), or evidence needed to support the search effort. The facts, data, information (backet) must have something to do with the problem or problem it faces [17]. With the successful collection of facts, data, materials, information (ballets), then processed according to the ability of human thinking (intelligence), then the data can be processed and analyzed to produce a conclusion. An intelligence estimate or estimate produces accurate ready-to-use information as an intelligence product that is ultimately ready to be used in making decisions. The final result of the data collection and processing activities or the basket is providing ready-to-use information as a product. 
The emphasis of intelligence is on the activities/activities of collecting, assessing, and analyzing data or information that is still raw into ready-to-use information and based on this ready-touse information, then making intelligence estimates as input for making a decision. Intelligence emphasizes other than as an activity, namely producing ready-touse information and making estimates/estimates of conditions or forecasts that are accurate and able to answer the questions of what, who, where, when, why, and how, this is necessary for decision making. Intelligence in this broad sense anatomically includes three dimensions of meaning, namely: first, intelligence as an organization; both intelligence as an activity; third intelligence as a product.

The Prosecutor's Office as one of the law enforcement agencies has a very important and vital role. The role of the Prosecutor's Office in the era of independence has been juridical since the promulgation of Law no. 15 of 1961 concerning the Basic Provisions of the Prosecutor's Office. After the proclamation of the independence of the Republic of Indonesia, all provisions that were in effect in the previous period were declared still valid. Likewise with the law governing the prosecution agency. The affirmation of the position and role and function of the prosecution agency is affirmed in Law no. 15 of 1961 concerning the Basic Provisions of the Prosecutor's Office. The law states that the Prosecutor's Office is a state law enforcement instrument that serves as a public prosecutor, the implementation of the tasks of the Prosecutor's Department is carried out by the Minister or the Attorney General.

Law No. 5 of 1991 concerning the Prosecutor's Office of the Republic of Indonesia places the Prosecutor's Office as a government institution that carries out state authority in the field of prosecution. This position brings the Prosecutor's Office as a prosecution agency in a dilemmatic position. As the executor of state authority in the field of prosecution, the vision and mission of the prosecutor's office should refer to the state's vision and mission as stated in the 1945 Constitution. Replacement of Law no. 5 of 1991 concerning the Prosecutor's Office of the Republic of Indonesia into Law no. 16 of 2004 concerning the Attorney General's Office of the Republic of Indonesia is driven by the spirit of reform, one of which is fair and independent law enforcement.

In Article 9 letter d of Law Number 17 of 2011, the Intelligence of the Prosecutor's Office of the Republic of Indonesia as State Intelligence is tasked with carrying out Intelligence functions in the field of law enforcement. The intelligence agency of the Prosecutor's Office of the Republic of Indonesia is an integral part of the national security system and holds the position of the organizer of the national intelligence agency authorized to carry out the functions and activities of the national intelligence agency. The State Intelligence Service itself is investigating, security, and mobilizing.

In carrying out the duties, authorities, and functions of the Prosecutor's Office in the field of intelligence in its jurisdiction as referred to in Article 994, letter $\mathrm{E}$ in the Regulation of the Attorney General of the Republic of Indonesia Number PER006/A/JA/07/2017 concerning the Organization and Work Procedures of the Prosecutor's Office of the Republic of Indonesia, the Intelligence Section organizes the functions of planning, implementing, administering, controlling and reporting on the provision of technical intelligence support to other fields within the jurisdiction based on the principle of coordination. Intelligence support is further explained in Article 1 paragraph 14 of the Regulation of the Attorney General of the Republic of Indonesia Number: PER-037/A/JA/9/2011 concerning Standard Operational Procedures for Intelligence of the Attorney General of the Republic of Indonesia:

"Intelligence support is assistance provided by the intelligence sector of the Prosecutor's Office to support the success of the main tasks in the fields of Guidance, General Crimes, Special Crimes, Supervision, Civil and State Administration as well as the Indonesian Attorney's Education and Training Agency."

The Intelligence Section has the task of carrying out the preparation of the formulation of work plans and programs as well as reports on their implementation, planning, assessment, implementation, administration, control, assessment, and reporting of technical policies, intelligence activities, intelligence operations, government escort and security and development, intelligence administration, and providing support. technical intelligence to other fields, planning, implementation and reporting of mapping, planning, management and reporting of information technology, planning, implementation, administration, and reporting of activities in the field of legal information, preparation, presentation, administration, distribution and archiving of periodic reports, reports incidentals, estimates of the state of intelligence, results of the implementation of work plans and work programs, intelligence activities and intelligence operations,government escort and security and strategic project development, planning, management, and reporting of intelligence data banks and information security, control of intelligence administration, maintenance of intelligence equipment, planning, and implementation of 
coordination and/or cooperation with local governments, state-owned enterprises Regions, agencies, and organizations, providing guidance and technical guidance on intelligence and intelligence administration, and preparing materials for evaluating Sandiman's functional performance related to the fields of ideology, politics, defense, security, social, culture, society, economy, finance, securing strategic development, intelligence technology, intelligence production, and legal information [18].

The provisions in the latest Attorney's Bill also regulate law enforcement intelligence or judicial intelligence adapted to the State Intelligence Law, strengthening the human resources of the Prosecutor's Office through the development of education in the fields of profession, academics, expertise, and service, as well as affirming the role of the Prosecutor's Office in maintaining the integrity and sovereignty of the state and nation when the state is in danger, civil and military emergency, and in a state of war.

Literally or in a narrow sense intelligence comes from the word intelligence, intellectual or human reasoning, namely how humans with intelligence or reasoning power try to be able to live in an increasingly complex society, be able to solve the problems they face, through the process of learning and taught and forged by long human experience then intelligence or human reasoning power continues to develop and humans try to make intelligence or reasoning abilities in science or scientifically become intelligence abilities, finally, humans succeed in developing intelligence or reasoning power into intelligence science.

With the support of advanced science and technology and supported by adequate funds and carried out with reliable management, intelligence science will continue to grow and become more stable and its existence is indispensable for humans to solve various problems of human life, where nowadays almost all countries have organizations or organizations. independent intelligence agency. Today's intelligence has almost touched all fields and sectors of people's lives. Intelligence in a broader sense anatomically includes three dimensions of meaning, namely first intelligence as an organization, second intelligence as an activity that is described in the functions of investigation, security, and raising, and third intelligence as a product [19].

The Intelligence Agency as an organization is an agency, agency, or work unit that is functionally based on the functions and competencies possessed and professionally based on professional expertise specifically dealing with issues related to intelligence, which are formally carried out by the state, government, or defense and security apparatus and law enforcement officers and nowadays intelligence investigation, security and raising activities can be carried out by individuals, communities, corporations, the private sector, NGOs, both organized and unorganized.

Nowadays intelligence almost touches all fields and sectors of people's lives, economy, politics, business, law and requires intelligence that can be used as a knife to analyze the problems faced. Intelligence is not solely owned by the state, government, defense and security apparatus, law enforcement officers, but the public can also have intelligence capabilities to maintain and develop themselves, even in advanced industrial countries intelligence is also used by individuals or corporations.

Intelligence as this product is the output of the results of the investigation, security, and raising activities carried out by organizations, agencies, services, or intelligence work units. Intelligence as an intelligence product or product is a paper in the field of intelligence that contains a description of the results that have been achieved in outlining the functions of investigation, security, and raising in addition to intelligence products.

The production process of an intelligence product includes activities to find, explore, collect and process data based on a production process, where the keyword of the intelligence production process lies in the ability to analyze all incoming input data. This analysis process includes separating, distributing, and describing all incoming input component data, the results of which will contain an explanation or explanation because the input data is raw and cannot speak much and only after being processed, processed, and analyzed will produce results. explanation or description.

Thus, the importance of the wiretapping authority possessed by the Prosecutor's Intelligence is to facilitate the Prosecutor's Intelligence in uncovering criminal acts of corruption. So far, in disclosing criminal acts of corruption, the Prosecutor's Intelligence only carries out their duties after a corruption crime has occurred. The Prosecutor's Intelligence should have started to carry out its duties as law enforcers in preventing corruption through wiretapping authority.

The power of wiretapping the Prosecutor's Intelligence must be regulated in the Prosecutor's Law, as legal legitimacy to the authority to wiretap the Prosecutor's Intelligence. Because basically, the Prosecutor's Intelligence carries out its duties and functions as both investigators and prosecutors must have special authority in terms of disclosing criminal 
acts of corruption before the crime occurs, considering that corruption is the biggest crime in Indonesia.

\section{B. The Intelligence Wiretapping Authority of the Prosecutor's Office from a Human Rights Perspective}

The right to privacy is part of the human right defined as freedom of privacy [8]. The right to privacy is regulated by Article 12 of the Declaration of Human Rights and Article 17 of the International Covenant on Civil and Political Rights, which may be arbitrarily disturbed (privacy, family, home, correspondence) or attacked by anyone. It will not be done. About their honor and their reputation. Everyone has the right to legal protection from such interference and attacks [20].

This article was later ratified by Indonesia through Law No. 12 of 2005 concerning the Ratification of the International Covenant on Civil and Political Rights. The article states that no one may arbitrarily or unlawfully interfere in his affairs (personal, family, home, or correspondence), or unlawfully attack his honor and reputation.

General Opinion No. 16 stated by the United Nations Commission on Human Rights on the 23rd states that Article 17 gives all rights to be freed from arbitrary or illegal interference in personal, family, household, and communication issues. Said to give to people. Like from unauthorized attacks protected for his honor and reputation. The Commission believes that this right should be guaranteed against all interference and attacks by public authorities, civilians, or the law.

In addition, Article 17 of the International Covenant on Civil and Political Rights states in point 8 as follows "...that the integrity and confidentiality of correspondence must be guaranteed de jure and de facto. Correspondence must be delivered to the intended address without hindrance and without being opened or read first. Surveillance, whether electronic or otherwise, wiretapping of telephones, telegraphs, and other forms of communication, and recording of conversations should be prohibited."

In Indonesia, the right to privacy or personality is regulated in the constitution, in the Special Chapter which regulates "Human Rights," namely in Chapter XA of the Second Amendment of the 1945 Constitution. The content of this chapter extends Article 28 of the 1945 Constitution. Originally it consisted of one article and one paragraph, but it consisted of several chapters and several sections. These articles and paragraphs are contained in Articles 28A-28J.

Every human being has the right to obtain protection (personal, family, honor, dignity, and property) under his control. Humans are also entitled to security and protection from the threat of fear to do or not do something (not violating the law) which are human rights. Regulations regarding privacy or personal rights are regulated in Article 28G paragraph (1) of the 1945 Constitution.

In the understanding of the rule of law, the guarantee of the protection of human rights is considered an absolute feature that must exist in every country which can be called rechtsstaat. Even in subsequent developments, the guarantees of human rights are also required to be explicitly stated in the constitution or the written constitution of a constitutional democracy [21].

The government of the Constitutional State must regulate the enforcement of these human rights, that is, to guarantee its enforcement and to regulate the borders for the public good and the benefit of the state. There is an opinion that divides the notion of human rights into vertical and horizontal meanings. Human Rights according to the 'vertical' sense, namely protecting individuals or groups from unfair interference from the government, while according to the 'horizontal' understanding refers to the relationship between fellow citizens. In this case, the government must protect individuals from violating their rights by other individuals [22].

In Indonesia, guarantees for the protection of human rights, apart from being contained in Chapter $\mathrm{XA}$ of the Constitution on Human Rights, are also stated in Article 2 of Law no. 39 of 1999 concerning Human Rights which states that the Republic of Indonesia recognizes and upholds human rights and basic human freedoms as rights that are inherently inherent in and inseparable from humans, which must be protected, respected, and enforced for the sake of increasing human dignity, welfare, happiness, and intelligence and justice [23].

Regarding the protection of human rights from wiretapping, Article 32 of Law no. 39 of 1999 states that independence and confidentiality in correspondence. Including communication through electronic means, it must not be disturbed except by order of a judge or other legal proxy following the provisions of the legislation [24].

Provisions regarding protection from wiretapping are also contained in other regulations, including Article 40 of Law Number 36 of 1999 concerning Telecommunications which explains that everyone is prohibited from conducting wiretapping activities and Article 19 paragraph (2) of Law no. 18 of 2003 concerning Advocates provides protection from wiretapping.

Article 31 of Law No.19 of 2016 regarding Amendments to Law No. 11 of 2008 regarding Electronic Information and Transactions additionally regulates the safety from wiretapping with the aid of using prohibiting any man or woman deliberately and 
without rights or a crime from interception or wiretapping of Electronic Information and/or Electronic Documents in a positive man or woman`s Computer and/or Electronic System. Also, a person who knowingly or illegally intercepts the transmission of electronic information and/or electronic documents not published to or in a particular computer and/or an electronic system owned by another person. Prohibit. It leads to all changes or one change and causes omissions.

Article 28I, paragraph 1 of the 1945 Constitution states the right to life, the right not to be tortured, the right to freedom of thought and conscience, the right to religion, the right not to be enslaved, and the right to approval. The right to be exempted as a person before the law and for retroactive legal grounds is a human right that cannot be restricted under any circumstances. This statement was later included in Article 4 of Law No. 39 of 1999 on Human Rights.

Human rights that cannot be reduced under any circumstances as described above can be classified as non-derogable rights as opposed to derogable rights, namely Human Rights which can be reduced in fulfillment in certain circumstances.

If you look at the description above regarding what human rights cannot be reduced under any circumstances (non-derogable rights), then the rights of privacy, including the right to wiretapping, are not human rights. which cannot be reduced under any circumstances (non-derogable rights). This shows that the fulfillment of rights of privacy can be reduced in certain circumstances (derogable rights).

References to the right to reduce an individual's rights, that is, a human right whose performance may be restricted under certain circumstances, were established by the Constitutional Court in Decision No. 5 / PUUVIII / 2010, where eavesdropping is in fact. Infringement of rights. Privacy is contrary to the 1945 Constitution. The right to privacy is part of human rights and can be harmful, but restrictions on the right to privacy shall only be imposed by law, as provided in Article 28J (2) of the 1945 Constitution.

With regard to the limitation of individual rights, as already mentioned, Article 17 of the International Covenant on Civil and Political Rights provides arbitrary or illegal interference with personal, family, home, or communication issues, and is illegal. It gives everyone the right to be protected from attacks. It is an honor and a reputation in itself. However, in this case, General Opinion No. 16 agreed by the United Nations Commission on Human Rights states points 3, 4, and 8.

The authority of investigators to conduct wiretapping is also evident in the Elucidation of Article 26 of Law no. 31 of 1999 concerning the Eradication of Corruption Crimes which states that the investigator's authority includes the authority to conduct wiretapping.

Section 42 (2) of Law No. 36 of 1999 on Telecommunications also records information sent and received by telecommunications service providers for criminal proceedings: a) Attorney General and/or written request from the head of the Indonesian National Police regarding certain criminal acts. b) Requests from investigators for certain criminal acts are governed by applicable law.

Further rules on eavesdropping are related to the Anti-Corruption Commission, Section 12 (1) lit of 2002. It is listed in 30. This provides that KPK is authorized to eavesdrop and record conversations when investigating, investigating, and prosecuting corruption crimes. Article 31 of Perppu No. 1 of 2002 on the Elimination of the Criminal Terrorism Act also regulates the interception of information in Law No. 15 of 2003 on Perppu Rule No. 1 of 2002 on the abolition of the Criminal Terrorism Act. It has the following provisions.

- Based on sufficient preliminary evidence, the investigator has the right to open, examine, and confiscate letters and items by post or other delivery services that are related to the case of a criminal act of terrorism being investigated; wiretapping conversations by telephone or other means of communication that are suspected of being used to prepare, plan, and commit acts of terrorism.

- Wiretapping can only be carried out by order of the Head of the District Court for a maximum period of 1 (one) year

- Such actions must be reported or accounted for by the investigator's superior.

Furthermore, Article 78 of Law no. 35 of 2009 concerning Narcotics stipulates that:

- In urgent circumstances and the investigator must conduct wiretapping, wiretapping can be carried out without prior written permission from the head of the district court;

- Within a period of no later than 1 x 24 (one time twenty-four) hours, the investigator must request written permission from the chairman of the district court regarding the wiretapping as referred to in paragraph (1).

UU no. 17 of 2011 concerning State Intelligence provides the authority to conduct wiretapping as stated in Article 31, namely that the State Intelligence Agency has the authority to conduct wiretapping, examine the flow of funds, and extract information on targets related to:

- Activities that threaten national interests and security include ideology, politics, economy, 
society, culture, defense, security, and other areas of community life such as food, energy, natural resources, and the environment, and/or;

- Terrorism, separatism, espionage, and sabotage threaten national security and sovereignty, including those currently being prosecuted.

In other countries, namely the $\mathrm{UK}$, in a regulation called The Regulated of Investigatory Power, investigators can ask the judicial power to provide an affidavit by swearing before a judge that the investigator will obtain the recording, but not violate its confidentiality [26]. According to the book "English-Indonesian Legal Terminology" by IPM Ranuhandoko BA, the affidavit is defined as "a statement written on oath by the maker, before the competent authority [27]. The recordings obtained by the investigators were only opened at the time of the court hearing, however, the recordings that were opened were chosen between those that were eligible to be opened and those that were not eligible to be opened.

In the United States, eavesdropping complies with Title III of the Comprehensive Crimes and Safe Street Act of 1968, which stipulates that eavesdropping must be approved in court. However, there are exceptions to this rule. That is, it is characteristic of eavesdropping of communications in an emergency that threatens the safety of others' lives, conspiracy activities that threaten national security, and conspiracy activities of criminal organizations. [28]. In America, disclosure of privacy by investigation or stolen or intentionally leaked to the mass media is a criminal act.

The ability to conduct wiretapping as a form of limitation by law on the protection of human rights is like a knife that must be used wisely. If used in the right way, by fulfilling all the requirements that have been determined, then the community will benefit from being able to reveal various crimes that are difficult to prove. However, if it is used in the wrong way, without fulfilling all the requirements that have been determined, it can hurt the community because what happens is arbitrariness.

\section{CONCLUSION}

The Legal Urgency of the Prosecutor's Intelligence Authority in the Law concerning the Prosecutor's Office of the Republic of Indonesia The intelligence of law enforcement carried out by the Prosecutor's Office cannot be separated from the mandate of the Prosecutor's Law, namely that the Prosecutor's Office must also be able to be fully involved in the development process. This includes helping to create conditions that support and ensure the implementation of development to create a just and prosperous society based on Pancasila. In addition, it is also obligatory to participate in maintaining and upholding the sovereignty of the government and the state and protecting the interests of the community. Wiretapping in the perspective of human rights is a form of violation of human rights, namely the right to privacy. The regulation on the protection of human rights from wiretapping is contained in various regulations that indicate the existence of guarantees for the protection of human rights. Wiretapping can be carried out as a form of limitation by law on the protection of human rights on the condition that certain conditions have been met so as not to cause arbitrariness.

\section{REFERENCES}

[1] LMFriedman, The Legal System; A Social Perspective, (New Yoork, Russel Sage Foundation, 1975), p. 11.

[2] Marwan Effendy, Indonesian Attorney's Office Position and Function from a Legal Perspective, (Jakarta: PT. Gramedia Pustaka Utama, 2005), p. 2

[3] Bagir Manan, 2005, An Authorized Judicial System, A Search, Supreme Court of the Republic of Indonesia, p. 15.

[4] Harkristuti Harkrisnowo, Redesigning the Adhyaksa Corps, (National Law Commission Newsletter, June 2003 Edition), p. 10

[5] Jemadu, Aleksius (ed), Democratic Intelligence and Surveillance Practices-Practitioner's View, DCAF-FES SSR Volume 2, Jakarta, 2007.

[6] Yudi Kristiana, Independence of the Prosecutor's Office in Corruption Investigations, PT. Citra Aditya Bakti, Bandung. 2006, p. 34.

[7] A Decade of Law No. 16 of 2004 Concerning the Indonesian Prosecutor's Office Towards a Better Public Prosecution

[8] Saidil Adri, The Role of Riau High Prosecutor's Intelligence in Disclosure of Alleged Corruption Crimes, JOM Faculty of Law, University of Riau Volume V Number 1 April 2018, p. $1-15$.

[9] Fahririn regarding the Implementation of the Duties and Authorities of the West Sumatra High Prosecutor's Investigator in the Context of Investigating Criminal Acts of Corruption, Supremacy Journal of Law Vol. 2, NO. 1 2019, p. 83-97.

[10] Abdul Azis, Monitoring the Performance of the Prosecutor's Office on the Criminal Justice Process. The article was submitted at the Prosecutor's Office Monitoring Workshop organized by MaPPI and the TIFA Foundation in Jakarta. 2830 June 2004

[11] Tohom Hasiholan, Optimizing the Duties and Authorities of the Prosecutor's Office in the Field of Public Order and Peace based on Article 30 Paragraph (3) of Law Number 16 of 2004 concerning the Prosecutor's Office in Relation to Supervision of Beliefs and Prevention of Abuse and/or Blasphemy of Religion (Pontianak District Attorney's Study), Published Scientific Manuscripts, p. 1-30.

[12] Soekanto, Soerjono and Sri Mamudji, (2007), Normative Legal Research, A Brief Overview. Jakarta: PT RajaGrafindo Persada.

[13] Prajogo. Soesilo, Dictionary of International and Indonesian Law. Intellectual Discourse.2007.

[14] Alexius Jemadu. 2007. "Terrorism, Intelligence Reform and the Protection of Civil Liberties in Indonesia" in Bob S. Hadiwinata and Christoph Schuck (eds.) Democracy in Indonesia: The Challenge of Consolidation. Baden - Baden: Nomos Verlagsgesselschaft. Thing. 301-304.

[15] Ignatius Melvin Tambunan, The Mechanism of Implementing Prosecutors' Intelligence in Revealing Corruption Crimes in the City of Yogyakarta, Scientific Journal, Faculty of Law, Atmajaya University Yogyakarta, 2015, p. 1-21. 
[16] M. Adi Togarisman, Prosecutor's Intelligence Investigations, Materials Presented at the 1st Class of 2010 Basic Intelligence Training, Prosecutor's Training Center, Jakarta, March 2010.

[17] Y. Wahyu Saronto, et al, Intelligence, PT. MUltindo Mga Pratama, 2008, p. 30.

[18] RM. Surachman, Authority of the Prosecutor's Office in the Application of the Principle of Opportunity in Indonesia, Bandung: PT. Citra Aditya, 2010, p.73.

[19] Arin Karniasari, "Theoretical, Historical, Juridical and Practical Overview of the Attorney General's Authority in Overriding Cases for the Public Interest" Thesis at the Faculty of Law, University of Indonesia, Postgraduate Program, 2012, p. 3.

[20] Taufiq Rahman, Basic Theory of Authority of Investigators and Public Prosecutors in Terminating Criminal Cases, Yuridika Vol. 25 No. 1, January-April 2010: 13-32

[21] RM Surachman and Andi Hamzah, Prosecutors in Various Countries, Their Roles and Positions, (Jakarta: Sinar Graphic, 1996), p. 6

[22] Djoko Prakoso, The Existence of Prosecutors in the Middle of Society, (Jakarta: Ghalia Indonesia, 1985), p. 89-90.
[23] Soeparman Parman, 2007, Introduction to the Right of Review in Criminal Cases for Victims of Crime, Bandung, PT Rafika Aditama, p. 59.

[24] Indonesian Armed Forces, National Defense Institute, 1988)

[25] Loch K. Johnson, Sketches for a Theory of Strategic Intelligence". Intelligence Theory "Key Questions and Debate, (New York, Routledge, Ed. Peter Gill, Stephen Marrin, and Mark Phytian, 2009)

[26] Thomas C. Breneau and Steven C. Boraz, Intelligence Reform: Balancing Democracy and Effectivenes, Reforming Intelligence. ed by Thomas C. Breneau and Steven C. Boraz, (USA, University of Texas Press, 2007)

[27] Arianto, Satya. (2015). Human Rights in Political Transition in Indonesia. cet. 4. Jakarta: Center for the Study of Constitutional Law, Faculty of Law, University of Indonesia.

[28] Baehr, Peter R. (1998). Human Rights in Foreign Policy [The Role of Human Rights in Foreign Policy]. translated by Soemardi. Ed.1. Jakarta: Indonesia Torch Foundation. Kansil, CST and Christine ST Kansil. (2003). About Human Rights Today, Jakarta: Djambatan. 